\title{
PENGARUH PENDIDIKAN KESEHATAN PENYAKIT JANTUNG KORONER TERHADAP SIKAP DAN MOTIVASI BERHENTI MEROKOK
}

\author{
Diyono, Ditya Yankusuma Setiani \\ AKPER PANTI KOSALA SURAKARTA, Sukoharjo, Jawa Tengah, Indonesia
}

\begin{abstract}
Abstrak
Latar Belakang. Prevalensi perokok di Indonesia cenderung meningkat mencapai $62,9 \%$ pada laki-laki dan $4,8 \%$ pada perempuan. Perlu dicari upaya yang lebih efektif untuk menurunkan prevalensi perokok.

Tujuan Penelitian. Mengetahui pengaruh pendidikan kesehatan penyakit jantung koroner terhadap sikap dan motivasi berhenti merokok.

Subjek dan Metode. Penelitian Quasi Eksperimen dengan desain prepost eksperimental. Sampel 42 perokok diambil secara random sederhana. Data dianalisis dengan Paired $t$ test.

Hasil. (1) Nilai rata - rata sikap berhenti merokok meningkat dari 28,7 menjadi 31,1 ; $p=0,019$ (2) Nilai rata - rata motivasi berhenti merokok meningkat dari 12,1 menjadi 16,7 ; $p=0,000$.

Kesimpulan. Pendidikan penyakit jantung koroner efektif untuk meningkatkan sikap dan motivasi berhenti merokok.
\end{abstract}

Kata kunci: berhenti merokok, motivasi, pendidikan kesehatan, sikap

\section{INFLUENCE HEALTH EDUCATION OF CORONARY HEART DESEASE TOWARD ATTITUDE AND MOTIVATION TO QUIT SMOKING}

\begin{abstract}
Background. The prevalence of smokers in Indonesia tends to increase reaching $62.9 \%$ in men and $4.8 \%$ in woman. That is need more effective efforts to be sought to reduce the prevalence of smokers.

The Aim of the Study. To know the effect of health education about coronary heart disease on smoking attitudes and motivation to quit smoking.

Subject and Method. Quasi experiment research by pre post design. A sample of 42 smokers was taken by simple random sampling. Data were analyzed by Paired t-test. Results. (1) The average value of smoking cessation attitude increased from 28.7 to 31.1; $p=0.019$. (2) The average value of quitting smoking motivation increased from 12.1 to $16.7 ; p=0.000$.

Conclusion. Coronary heart disease education is effective in improving attitude and motivation to stop smoking.
\end{abstract}

Keywords: attitudes, health education, motivation, quit smoking

Korespondensi: Diyono. AKPER PANTI KOSALA SURAKARTA. Jalan Raya Solo - Baki Km. 4 Gedangan, Grogol, Sukoharjo, Jawa Tengah. Email: dionsanfizio@gmail.com

\section{LATAR BELAKANG}

Angka perokok di Indonesia masih cukup tinggi. Hasil Riset Kesehatan Dasar menunjukkan perokok laki-laki meningkat $62,9 \%$ sedangkan pada perempuan hanya $4,8 \%$.
Berdasar tingkat usia mayoritas perokok di Indonesia paling tinggi dimulai pada usia 15 - 19 tahun, kemudian di bawahnya pada usia 20 - 24 tahun (Kemenkes RI, 2018). Penelitian terkait pengaruh pendidikan kesehatan terhadap 
upaya meningkatkan kesadaran masyarakat untuk berhenti merokok sudah banyak dilakukan. Mayoritas topik pendidikan kesehatan yang diberikan adalah tentang zat-zat kimia beracun yang ada di dalam rokok. Hasil penelitian terdahulu menurut Huriati dan Arbianingsih (2018), menunjukkan bahwa pendidikan kesehatan tentang bahaya rokok berpengaruh terhadap motivasi berhenti merokok. Pada penelitian ini, peneliti berupaya untuk mencari metode lain yaitu dengan memberikan pengetahuan tentang penyakit akibat rokok secara lebih detail yaitu penyakit jantung koroner.

\section{TUJUAN PENELITIAN}

Tujuan penelitian ini adalah Mengetahui pengaruh pendidikan kesehatan penyakit jantung koroner terhadap sikap dan motivasi berhenti merokok.

\section{METODE}

Metode penelitian quasy experiment dengan desain pre post experimental. Penelitian dilaksanakan mulai bulan Januari Maret 2020 di Desa Gulon Kecamatan Jebres Kota Surakarta. Data dianalisis dengan Paired t-test.

\section{SUBJEK}

Populasi pada penelitian ini adalah seluruh perokok yag ada di Desa Gulon Jebres Kota Surakarta. Jumlah sampel 42 perokok diambil secara random sederhana.

\section{HASIL}

1. Karakterisitik Responden

Tabel 1

Karakteristik Responden Penelitian Pengaruh Pendidikan Kesehatan PJK terhadap Sikap dan Motivasi Berhenti Merokok

\begin{tabular}{|c|c|c|c|c|c|}
\hline Demografi & $f$ & $\%$ & Kebiasaan Merokok & $f$ & $\%$ \\
\hline Jenis Kelamin & & & Lama Merokok & & \\
\hline Laki-Laki & 42 & 100 & $<1$ tahun & 6 & 14,3 \\
\hline \multirow[t]{2}{*}{ Perempuan } & 0 & 0 & $1-5$ tahun & 16 & 38,1 \\
\hline & & & $>5$ tahun & 20 & 47,6 \\
\hline \multicolumn{6}{|l|}{ Tingkat Pendidikan } \\
\hline Dasar & 3 & 7,1 & Jumlah Rokok & & \\
\hline Menengah & 33 & 78,6 & $<10$ batang & 29 & 69,0 \\
\hline \multirow[t]{2}{*}{ Tinggi } & 6 & 14,3 & $10-20$ batang & 2 & 04,7 \\
\hline & & & $>20$ batang & 11 & 26,3 \\
\hline \multicolumn{6}{|l|}{ Umur } \\
\hline $20-30$ & 21 & 50,0 & & & \\
\hline $31-40$ & 8 & 19,0 & & & \\
\hline $41-50$ & 7 & 16,7 & & & \\
\hline$>50$ & 6 & 14,3 & & & \\
\hline
\end{tabular}




\section{Pengaruh Pendidikan Kesehatan PJK Terhadap Sikap Berhenti Merokok}

Tabel 2.

Hasil Paired Sample T-Test Penelitian Pengaruh Pendidikan Kesehatan Penyakit Jantung Koroner (PJK) terhadap Sikap Berhenti Merokok

\begin{tabular}{cccccc}
\hline Variabel & Mean & $\begin{array}{c}\text { Mean } \\
\text { Differences }\end{array}$ & $\begin{array}{c}\text { Sig. Paired } \\
\text { Simple } \\
\text { Correlation }\end{array}$ & $\mathrm{t}$ & Sig \\
\hline Pre & 28,71 & $-2,404$ & 0,66 & $-2,443$ & 0,019 \\
\hline
\end{tabular}

Hasil Paired Sample t-test seperti terlihat pada Tabel 2 di atas menunjukkan nilai Sig $=0,019$, yang berarti terdapat perbedaan yang signifikan antara nilai rata-rata sikap sebelum dengan sesudah diberikan pendidikan kesehatan penyakit jantung koroner. Berdasar nilai perbedaan rata-rata (mean differences) adalah negatif yaitu -
2,404 dapat diartikan bahwa nilai rata-rata setelah diberi perlakuan lebih tinggi dari pada nilai sebelum diberi perlakuan. Berdasar hasil uji statistik tersebut dapat disimpulkan bahwa pendidikan kesehatan tentang penyakit jantung koroner secara signifikan efektif untuk meningkatkan sikap berhenti merokok.

\section{Pengaruh Pendidikan Kesehatan PJK Terhadap Motivasi Berhenti Merokok}

Tabel 3.

Hasil Paired Sample T-Test Penelitian Pengaruh Pendidikan Kesehatan Penyakit Jantung Koroner (PJK) terhadap Motivasi Berhenti Merokok

\begin{tabular}{cccccc}
\hline Variabel & Mean & $\begin{array}{c}\text { Mean } \\
\text { Differences }\end{array}$ & $\begin{array}{c}\text { Sig. Paired } \\
\text { Simple } \\
\text { Correlation }\end{array}$ & $\mathrm{t}$ & $\mathrm{Sig}$ \\
\hline $\begin{array}{c}\text { Pre } \\
\text { Post }\end{array}$ & 12,14 & $-4,619$ & 0,73 & $-5,069$ & 0,000 \\
\hline
\end{tabular}

Hasil uji statisitik dengan Paired Sample t-test sebagaimana terlihat pada Tabel 3 menunjukkan nilai sig $=0,000$, sedangkan nilai perbedaan rata-rata (mean differences) adalah negatif yaitu 4,619 yang dapat diartikan bahwa nilai rata-rata setelah diberi perlakuan lebih tinggi dari pada nilai rata-rata sebelum diberi perlakuan, sehingga dapat disimpulkan bahwa pendidikan kesehatan tentang penyakit jantung koroner secara signifikan dapat meningkatkan motivasi berhenti merokok.

\section{PEMBAHASAN}

Merokok merupakan aktivitas menghisap asap dari pembakaran tembakau secara aktif maupun pasif. Upaya berhenti merokok bukan suatu hal yang mudah. Hal ini dikarenakan jika seseorang sudah mencoba merokok maka dapat menimbulkan ketagihan atau kecanduan. Hal ini tidak terlepas dari adanya zat yang ada di dalam asap rokok yang dapat menyebabkan ketagihan, yang dinamakan nikotin. Zat tersebut jika sampai ke sel otak akan merangsang munculnya endorfin, yaitu zat yang mirip morfin yang diproduksi oleh sel-sel otak.

Endorfin ini mempunyai efek relaksasi, sehingga orang yang merokok akan merasa rileks dan tenang dan sebaliknya jika tidak merokok orang akan merasa gelisah. Kadar endorfin yang diproduksi oleh otak sangat tergantung dari jumlah nikotin yang masuk ke sel otak. Semakin lama sel otak mendapatkan nikotin, maka 
semakin banyak pula otak menghasilkan endorfin. Sehingga jika otak tidak menghasilkan endorfin karena tidak ada nikotin yang masuk, maka sel otak akan menagih tubuh untuk memasukkan nikotin, sehingga merangsang orang untuk merokok kembali.

Oleh karena itu dibutuhkan upaya yang luar biasa untuk berhenti merokok atau setidaknya mengurangi jumlah rokok yang dihisap. Perilaku merokok merupakan suatu kebiasaan yang dibentuk dari pengetahuan dan sikap seseorang terhadap rokok. Untuk itu untuk merubah kebiasaan merokok juga harus dimulai dari hal yang sama, yaitu merubah sikap terhadap upaya berhenti merokok. Pemerintah melalui menteri kesehatan telah mengeluarkan Peraturan Menteri Kesehatan (PMK) Nomor 5 Tahun 2017 tentang pencantuman gambar peringatan bahaya rokok pada setiap bungkus dan iklan produk tembakau atau rokok sebagai upaya mengedukasi bahaya rokok terhadap masyarakat. Namun kenyataannya upaya tersebut belum mendapatkan hasil maksimal, yang ditunjukkan data prevalensi perokok di Indonesia yang cenderung masih meningkat. Penelitian terkait tentang upaya meningkatkan pengetahuan, persepsi dan sikap terhadap kebiasaan merokok juga sudah banyak dilakukan. Hasil penelitian ini semakin memperkaya temuan ilmiah atau penelitian yang sudah ada, terkait upaya menurunkan kebiasaan merokok melalui perbaikan sikap terhadap upaya berhenti merokok. Hasil penelitian berdasar uji Paired Sample t-test menunjukkan bahwa pendidikan kesehatan tentang penyakit jantung koroner secara signifikan efektif untuk meningkatkan sikap berhenti merokok $(p=0,019)$. Hasil penelitian ini pada dasarnya secara umum sejalan dengan penelitian terdahulu, diantaranya penelitian Diyono dan Anggraeni (2016), yang meneliti tentang hubungan persepsi label bahaya merokok dengan kebiasaan merokok dengan kesimpulan terdapat hubungan yang signifikan antara persepsi tentang label peringatan bahaya rokok pada kemasan rokok dengan kebiasaan merokok ( $p=0,000 ; r=0,391)$. Penelitian Oktaria, Indriansari dan Muharyani (2017), tentang faktorfaktor yang berhubungan dengan motivasi berhenti merokok pada sopir angkutan umum diperoleh kesimpulan terdapat hubungan antara persepsi dengan motivasi berhenti merokok. Penelitian Wiratini, Yanti dan Wijaya (2015) tentang pengaruh peer education terhadap perilaku merokok pada remaja, diperoleh nilai uji Wilcoxon $p<0,05$ yang berarti pendidikan bahaya rokok melalui peer education berpengaruh terhadap perilaku merokok. Adapun yang membedakan penelitian ini dengan penelitian terdahulu adalah jika pada penelitian terdahulu topik atau materi penyuluhan adalah isi, kandungan dan bahaya rokok, maka pada penelitian ini yang dijadikan sebagai materi atau topik pendidikan kesehatan adalah penyakit yang disebabkan oleh kebiasaan merokok yaitu penyakit jantung koroner. Pada penelitian ini responden diberikan paparan tentang penyakit jantung koroner sebagai salah satu penyakit akibat kebiasaan merokok yang mencakup pengertian, penyebab, patofisiologi, tanda dan gejala serta komplikasi yang cukup berat yaitu dapat terjadi serangan jantung dan kematian mendadak, membuat responden sangat takut yang kemudian mampu merubah sikap dari rata-rata kurang mendukung atau bersikap negatif terhadap upaya berhenti merokok, berubah menjadi mendukung untuk berhenti merokok. Hal ini terbukti dari nilai rata-rata (mean) sikap 
berhenti merokok meningkat dari 28,7 menjadi 31,1 . Walaupun dari nilai minimal dan maksimal lebih baik pada saat sebelum diberi pendidikan kesehatan, namun dari nilai range yaitu jarak antara yang paling sedikit dengan yang paling banyak menunjukkan penurunan yaitu dari 22,0 menjadi 21,0 . Selain itu nilai standar deviasi yang menurun dari 5,6 menjadi 5,0 juga menggambarkan bahwa setelah diberi pendidikan kesehatan, ratarata sikap responden berubah menjadi mendukung atau mempunyai penilaian positif terhadap upaya berhenti merokok.

Dalam hal pembentukan perilaku, sikap merupakan tahapan yang lebih tinggi daripada pengetahuan. Sikap atau attitude adalah istilah yang mencerminkan rasa senang, tidak senang atau perasaan biasabiasa saja (netral) dari seseorang terhadap sesuatu. "Sesuatu" itu bisa benda, kejadian, situasi, orangorang atau kelompok. Kalau yang timbul terhadap sesuatu itu adalah perasaan senang, maka disebut sikap positif, sedangkan kalau perasaan tak senang dinamakan sikap negatif dan kalau tidak timbul perasaan apa-apa, berarti sikapnya netral (Sarwono, 2014). Sikap atau penilaian positif terhadap upaya berhenti merokok dapat menjadi kunci pembuka munculnya perubahan perilaku berhenti merokok. Hal ini terjadi karena perilaku sangat dipengaruhi oleh sikap atau penilaian seseorang terhadap suatu hal atau obyek yang ada disekitarnya. Sobur (2011), menjelaskan bahwa sikap berbeda dengan pengetahuan, dimana sikap tidak dibawa sejak lahir, namun dapat dipelajari (learnbility) dan dibentuk berdasarkan pengalaman dan latihan sepanjang perkembangan individu dalam hubungan dengan objek di luar dirinya. Sikap juga sangat berkaitan dengan keinginan atau motivasi, dimana sikap dapat menggambarkan keinginan untuk mencapai suatu tujuan tertentu atau upaya penyesuaian individu dengan lingkungannya.

Menurut Sarwono (2014), salah satu faktor yang dapat menginisiasi proses pembentukan sikap adalah faktor traumatik, seperti pengalaman atau kejadian tidak menyenangkan yang datang secara tiba-tiba, atau informasi yang mengejutkan sehingga meninggalkan kesan mendalam pada jiwa seseorang. Penyakit jantung koroner merupakan salah satu penyakit yang dapat menyebabkan kematian secara mendadak (suddent death) yang sudah banyak diketahui oleh masyarakat. Kondisi ini dapat menjadi suatu trauma tertentu bagi individu yang kemudian akan mendorong percepatan pembentukan sikap. Pada materi pendidikan kesehatan yang diberikan, peneliti memberikan gambaran tingkat mortalitas (kematian) dan contoh-contoh aktual kematian mendadak yang dialami oleh pasien. Gambaran demikian ternyata merupakan pengalaman traumatik sendiri bagi responden, sehingga secara tidak sadar dapat menjadikan sikap responden berubah menuju ke arah positif atau mendukung diri sendiri atau orang lain untuk berhenti merokok.

Hasil uji statisitik dengan Paired Sample t-test sebagaimana terlihat pada Tabel 3 di atas menunjukkan Sig $=0,000$, nilai perbedaan rata-rata (mean differences) adalah negatif yaitu -4,619 dapat diartikan bahwa nilai rata-rata setelah diberi perlakuan lebih tinggi dari pada nilai rata-rata sebelum diberi perlakuan, sehingga dapat disimpulkan pendidikan kesehatan tentang penyakit jantung koroner secara signifikan dapat meningkatkan motivasi berhenti merokok.

Motivasi menurut Sudarma (2011), adalah daya pendorong seseorang 
untuk mewujudkan keinginan. Motivasi pada dasarnya adalah sebuah energi pendorong seseorang untuk melakukan suatu tindakan. Ada tiga hal penting dalam pengertian motivasi, yaitu hubungan antar kebutuhan, dorongan dan tujuan. Kebutuhan muncul karena seseorang merasakan sesuatu yang kurang, baik fisiologis maupun psikologis. Salah satu jenis motivasi menurut Sunaryo (2013), adalah motivating by indentification atau ego-involvement atau memotivasi dengan identifikasi, yaitu cara memotivasi dengan menanamkan kesadaran sehingga individu berbuat sesuatu karena adanya keinginan yang timbul dari kesadaran yang ada dalam dirinya sendiri.

Kesadaran merupakan komponen pikiran abstrak yang terbentuk dari analisis pengetahuan seseorang. Dalam konsep berubah, kesadaran atau awareness merupakan kunci seseorang mengadopsi suatu perilaku yang baru. Pendidikan kesehatan merupakan salah satu cara untuk meningkatkan pengetahuan, sehingga secara langsung maupun tidak langsung akan mempengaruhi sikap dan kesadaran, yang pada akhirnya mampu merubah niat atau motivasi seseorang untuk melakukan suatu perilaku tertentu. Pada penelitian ini pengetahuan yang ditambahkan pada responden tidak lagi pada topik bahaya rokok namun pada salah satu penyakit akibat kebiasaan merokok yaitu penyakit jantung koroner. Metode ini peneliti pilih karena merokok terbukti merupakan faktor resiko atau pencetus terbesar terjadinya kematian mendadak akibat gangguan jantung. Resiko terjadinya penyakit jantung koroner meningkat 2-4 kali pada perokok dibandingkan dengan bukan perokok. Resiko ini meningkat dengan bertambahnya usia dan jumlah rokok yang dihisap.
Akibat penggumpalan (trombosis) dan pengapuran (arterosklerosis) dinding pembuluh darah, merokok jelas akan merusak pembuluh darah perifer (Proverawati dan Rahmawati, 2012).

Motivasi mempunyai fungsi penting dalam setiap perbuatan atau perilaku manusia. Menurut Sumar (2016), motivasi paling tidak mempunyai 3 fungsi yaitu mendorong timbulnya kelakuan atau suatu perbuatan, sebagai pengarah perbuatan untuk mencapai tujuan yang diinginkan dan sebagai penggerak perbuatan, dimana besar kecilnya motivasi akan menentukan cepat atau lambatnya suatu perbuatan. Berhenti merokok juga merupakan suatu perbuatan atau perilaku, yang pada kenyataannya bukan merupakan suatu hal yang mudah bagi seorang pecandu rokok, dan dibutuhkan motivasi yang sangat kuat untuk mau berhenti merokok. Hasil penelitian ini memberikan bukti empiris bahwa melalui pendidikan kesehatan tentang penyakit jantung koroner sebagai salah satu penyakit yang disebabkan oleh kebiasaan merokok efektif untuk meningkatkan motivasi berhenti merokok. Motivasi yang sudah terbentuk secara kuat dapat mendorong seseorang untuk berhenti merokok. Hal ini sejalan dengan hasil penelitian terdahulu yaitu penelitian Gerritsen, et al (2015), yang meneliti tentang SelfReporting of Smoking Cessation in Cardiac Patients: How Reliable Is It and Is Reliability Associated with Patient Characteristics, menyimpulkan bahwa motivasi pasien penyakit jantung untuk berhenti merokok lebih tinggi dibanding dengan pasien lain yang belum pernah atau tidak sakit jantung $(p=0,020)$. Pengetahuan yang diperoleh dari proses pembelajaran lewat pendidikan kesehatan maupun pengalaman sakit jantung ternyata sama-sama 
dapat meningkatkan motivasi untuk berhenti merokok. Pada penelitian ini responden yang peneliti pilih sesuai kriteria inklusi adalah perokok yang belum pernah mempunyai riwayat penyakit jantung, sehingga motivasi berhenti merokok murni meningkat karena adanya perubahan atau peningkatan pengetahuan setelah diberi pendidikan kesehatan, bukan karena pengalaman menderita penyakit jantung. Dengan kata lain bahwa pendidikan kesehatan tentang penyakit jantung koroner memang secara signifikan efektif untuk meningkatkan motivasi berhenti merokok pada seseorang yang mempunyai kebiasaan merokok.

Penelitian lain yang sejalan dengan hasil penelitian ini adalah penelitian Hoog, et al. (2016), tentang smoking cessation in cardiac patients: the influence of action plans, coping plans and self-efficacy on quitting smoking, diperoleh kesimpulan kemauan diri sendiri merupakan prediktor utama dalam upaya berhenti merokok dibanding umur, lingkungan, dan dukungan orang lain. Motivasi merupakan tenaga pendorong yang berasal dari dalam diri seseorang, berupa kemauan atau keinginan untuk berbuat sesuatu. Jika di dalam pikiran seseorang sudah muncul kemauan untuk berhenti merokok, maka hal itu merupakan energi yang lebih kuat dibanding faktor eksternal lain untuk mendorong atau memotivasi seseorang melakukan perbuatan sesulit apapun, termasuk untuk berhenti merokok. Penelitian Huriati dan Arbianingsih (2018), juga memberikan bukti yang mirip dengan hasil penelitian ini, dimana berdasar hasil uji statistik Paired $t$ test dan Independent t-test diperoleh kesimpulan bahwa pendidikan kesehatan tentang bahaya zat racun rokok terhadap kesehatan, melalui media facebook $(p=0,001)$ dan media leaflet $(p=0,002) \quad$ efektif untuk meningkatkan motivasi berhenti merokok pada remaja. Namun yang berbeda dengan penelitian ini adalah materi pendidikan kesehatan yang diberikan adalah langsung pada topik bahaya rokok terhadap kesehatan.

Kebiasaan merokok merupakan faktor resiko penyakit jantung koroner yang dapat diubah. Merokok merupakan salah satu faktor resiko penyakit jantung koroner yang paling kuat. Nikotin akan menurunkan aliran darah ke ekstremitas, serta meningkatkan frekuensi jantung dan tekanan darah dengan menstimulasi sistem syaraf simpatis. Pola untuk berhenti merokok dapat menurunkan resiko penyakit jantung koroner (Asikin, Nurlamsyah dan Susaldi, 2016). Melalui pendidikan kesehatan penyakit jantung koroner ternyata dapat menambah dan memperkuat pemahaman responden tentang merokok sebagai faktor resiko penyakit jantung koroner. Kebiasaan merokok dapat diubah tergantung dari niat atau motivasi seseorang, sehingga pengetahuan yang cukup tentang penyakit jantung koroner terbukti secara efektif dapat memunculkan keinginan atau motivasi dari dalam diri sendiri untuk berhenti merokok.

\section{KESIMPULAN}

Pendidikan kesehatan tentang penyakit jantung koroner efektif untuk meningkatkan sikap dan motivasi berhenti merokok.

\section{SARAN}

Perawat dan tenaga kesehatan yang lain diharapkan dapat meningkatkan sikap dan motivasi pasien untuk berhenti merokok dengan edukasi dan konseling tentang penyakit yang disebabkan oleh kebiasaan merokok dengan metode yang lebih bervariasi. Untuk 
peneliti selanjutnya diharapkan dapat melakukan penelitian yang lebih komprehensif tentang berbagai metode pendidikan kesehatan dan edukasi tentang upaya menurunkan kebiasaan merokok.

\section{DAFTAR PUSTAKA}

Asikin, Nurlamsyah dan Susaldi. 2016. Keperawatan Medikal Bedah : Sistem Kardiovaskular. Penerbit Erlangga, Jakarta.

Diyono dan D. Anggraini. 2016. "Hubungan Persepsi terhadap Label Peringatan Bahaya Rokok dengan Kebiasaan Merokok di Kelurahan Nusukan Banjarsari Kota Surakarta. Jurnal IImu Kesehatan Kosala. Vol. 4 No. 1. Akademi Keperawatan Panti Kosala Surakarta.

Gerritsen M., et al. 2015. "SelfReporting of Smoking Cessation in Cardiac Patients: How Reliable Is It and Is Reliability Associated With PatientCharacteristics?". J Addict Med. Vol.00 No.00. American Society of Addiction Medicine.

Hoog, N. D., et al. 2016. "Smoking Cessation in Cardiac Patients: The Influenceof Action Plans, Coping Plans and Self-Efficacy onQuitting Smoking". Health Education Research. Vol. 31 No. 3. Oxford University.

Huriati, M. R. dan Arbianingsih. 2018. Perbedaan Efektivitas Pendidikan Kesehatan Media Facebook dan Media Leaflet terhadap Motivasi Berhenti Merokok pada Remaja. http://journal.uinalauddin.ac.id/index.php/join/arti cle/view/5477. Diakses pada tanggal 18 April 2019.
Kemenkes RI. 2018. Riset Kesehatan Dasar tahun 2018. Kemenkes, Jakarta.

Oktaria, A. Indriansari dan P. W.Muharyani. 2017. "FaktorFaktor yang Berhubungan dengan Motivasi Berhenti Merokok pada Sopir Angkutan Umum". Jurnal IImu Keperawatan Sriwijaya. Vol. 4 No. 1. Universitas Sriwijaya Sumatra Selatan.

Proverawati, A. dan E. Rahmawati. 2012. Perilaku Hidup Bersih dan Sehat (PHBS). Nuha Medika, Yogyakarta.

Sarwono, S. W. 2014. Pengantar Psikologi Umum. Rajawali Pers, Jakarta.

Sobur, A. 2011. Psikologi Umum. Pustaka Setia, Bandung.

Sudarma, R. 2011. Buku Untaian Motivasi Menggapai Pribadi Lebih Bermakna. https://books.google.co.id/book. Diakses pada tanggal 15 April 2019.

Sumar, W. T. 2016. Solusi Mahir Kimia.

https://books.google.co.id/book. Diakses pada tanggal 15 April 2019.

Sunaryo. 2013. Psikologi untuk Keperawatan. EGC, Jakarta.

Wiratini N.P.S., N. L. P. E. Yanti. dan A. A. N. T. Wijaya. "Pengaruh Peer Education Terhadap Perilaku Merokok pada Remaja di SMA $X$ Denpasar". Couping Ners Journal. Vol. 3 No. 3 . Universitas Udayana Bali. 